\title{
Assessing Quality of Reporting of Herbal Dermatology Trials from the Philippines using the hCONSORT Checklist: a Systematic Review
}

\author{
Rowena Natividad S. Flores-Genuino, ${ }^{1,2}$ Maria Christina Filomena R. Batac ${ }^{3}$ and Kyle Mica D. Talens ${ }^{4}$ \\ ${ }^{1}$ Department of Anatomy, College of Medicine, University of the Philippines Manila, Manila, Philippines \\ ${ }^{2}$ Department of Dermatology, Makati Medical Center, Makati, Philippines \\ ${ }^{3}$ Section of Dermatology, Department of Medicine, College of Medicine and Philippine General Hospital, University of the Philippines Manila, Manila, Philippines \\ ${ }^{4}$ Quezon City, Philippines
}

\begin{abstract}
Background. Herbal medicine is a growing and innovative field in Philippine dermatology. There is a need to assess the quality of reporting of published herbal randomized controlled trials (RCTs) in dermatology since these will serve to guide rational development and use of medicinal plants in the Philippines.

Objective. The study aimed to assess the quality of reporting of published herbal RCTs in dermatology from the Philippines based on the hCONSORT checklist.

Methods. We searched MEDLINE, CENTRAL, HERDIN (from inception to 20 September 2018), and other secondary sources for published randomized controlled trials that used any herbal preparation as intervention for the treatment or prevention of a dermatologic disease or for maintenance of healthy skin, hair, or nails. We determined the percentage of reported items based from the hCONSORT checklist.

Results. We included 41 trials, majority of which were on infections, infestations, and bites (66\%). The three most common families of herbs used were Fabaceae/Leguminosae (22\%) (Gliricidia sepium (Jacq.) Walp. [kakawati]; Senna alata (L.) Roxb. / Cassia alata (L.) [akapulko]); Arecaceae (12\%) (Cocos nucifera L. [coconut]); and Myrtaceae (12\%) (Eucalyptus sp [eucalyptus], Psidium guajava L.[guava], and Melaleuca alternifolia (Maiden \& Betche) Cheel [tea tree]). Most of the trials $(27 / 41,66 \%)$ were conducted in accredited dermatology training programs of the Philippine Dermatological Society. Only 11 trials (27\%) were published in PubMED-indexed journals. More than half of articles were published after the CONSORT publication in 2006 (59\%). The mean percentage of reported hCONSORT checklist items in included studies was 39.6\% (SD 9.9), with only seven studies reporting more than $50 \%$ of the hCONSORT checklist items.
\end{abstract}

Conclusion. Published herbal RCTs in dermatology from the Philippines are poorly reported based on the hCONSORT checklist. There is a need for dissemination of the hCONSORT to local researchers and journal editors to ensure thorough and quality reporting.

Key Words: randomized clinical trials, herbal, botanical, plant-based, CONSORT, hCONSORT, quality of reporting, systematic review

\section{INTRODUCTION}

E-poster presentation, World Congress of Dermatology (WCD 2019), June 10-15, 2019, Milano Congressi, Milan, Italy.

Corresponding author: Rowena Natividad S. Flores-Genuino, MD, MSc

Department of Anatomy

College of Medicine

University of the Philippines Manila

547 Pedro Gil St., Ermita, Manila 1000, Philippines

Email: rfgenuino@post.upm.edu.ph
Herbal medicines are widely used in the Philippines, being a tropical country with diverse flora. In 1997, the Philippine government enacted Republic Act 8423 to accelerate the development of traditional and alternative health care in the Philippines. ${ }^{1}$ To integrate herbal medicine into the national health care delivery system, the Philippine Department of Health recommended ten medicinal plants for local use, including Senna alata (L.) Roxb. (akapulko) 
lotion for tinea versicolor. However, there was limited local marketing of akapulko lotion in the 1990s. ${ }^{2}$

In a content analysis of herbal research studies published in the Journal of the Philippine Dermatological Society (JPDS), RCTs were the most common study design (18/27), with infestations, infections, and bites as the most commonly studied conditions (18/27), and Citrus microcarpa Bunge (kalamansi) and Cocos nucifera L.(coconut) (3/27 each) as the most commonly studied medicinal plants. Majority of studies were published between 2002 to $2011 .^{3}$

Randomized controlled trials (RCTs) are clinical trials that involve at least one test treatment and one control treatment, in which the treatments to be administered are selected through a random process. ${ }^{4}$ Considered the gold standard for ascertaining the efficacy and safety of an intervention, they are crucial to the practice of evidence-based medicine. Standardization of reporting of findings in RCTs by authors is essential to ensure complete and transparent reporting, and aid their critical appraisal and interpretation. Reporting guidelines serve as a checklist to remind researchers what information to include in the manuscript, and as a tool for peer reviewers to check the completeness of information in the manuscript. Good reporting leads to efficient use of available evidence for potential users such as systematic reviewers, clinical guidelines developers, clinicians, and sometimes patients. The EQUATOR (Enhancing the QUAlity and Transparency Of health Research) Network was launched in 2008 as a global initiative that "seeks to improve the reliability and value of published health research literature by promoting transparent and accurate reporting and wider use of robust reporting guidelines." Currently, there are 408 reporting guidelines in the EQUATOR database, 18 of which are meant to guide parallel group randomized trials. ${ }^{5}$

The CONSORT 2006 Statement Extension for Herbal Interventions is a list of evidence-based recommendations for reporting randomized trials that are specific for herbal intervention trials. ${ }^{6}$ Details of the herbal preparations are necessary since crude herbal products may differ according to geographic location and climate where they were grown, as well as the time of year when they were harvested. Aside from different extraction and processing methods between manufacturers, there may also be variations from batch to batch within the same manufacturer. Even if the main herbal ingredient is standardized, there are other ingredients that may vary between products.

Three systematic reviews on the quality of reporting of herbal RCTs showed varying compliance with the hCONSORT. A 2011 systematic review randomly selected 100 English language RCTs (Medical Literature Analysis and Retrieval System Online, Excerpta Medica Database, and Academy of Microscope Enhanced Dentistry; up to December 2007) that used 11 commonly used herbal medicine interventions. It showed that, on average, only $38 \%$ of the information suggested in the checklist was reported in the trials. ${ }^{7}$ Similarly, a 2018 systematic review on published
RCTs (EMBASE, MEDLINE, and CENTRAL, 20092014) of herbal interventions for three common dermatoses (acne, atopic dermatitis, and psoriasis), showed that majority $(22 / 26)$ of reviewed studies reported less than $50 \%$ of the recommended hCONSORT criteria. ${ }^{8}$ On the other hand, a 2015 systematic review of published herbal RCTs from ASEAN Plus Six Countries (PubMed, EMBASE, The Cochrane Library, and Allied and Complementary Medicine (AMED), up to October 2013) on 20 top herbal species listed in the National Essential List of Medicines of Thailand showed that 15/22 hCONSORT checklist items were reported by more than $80 \%$ of studies. ${ }^{9}$

Previous studies showed that variables such as type of journal, year of publication, and type of herb improved reporting quality. Peer-reviewed journal articles had significantly higher mean (SD) quality scores (0.94 [0.09] for systematic reviews and 0.30 [0.19] for nonsystematic reviews) compared with throwaway journal articles $(0.23$ [0.03], F2,391=280.8, P<.001). ${ }^{10}$ In a review of 211 RCTs published in four major journals (BMJ, JAMA, The Lancet, and NEJM), the number of CONSORT checklist items in reports of RCTs increased in all 4 journals in 1998, compared to 1994 , and this increase was statistically significant for the 3 adopter journals (pre-CONSORT 1996, 23.4; mean change, 3.7; 95\% confidence interval [CI], 2.1-5.3). ${ }^{11}$ The 2011 systematic review of herbal RCTs also showed better overall reporting in trials published in more recent years $(\mathrm{P}=0.02)$ and those that used the herb, North American ginseng $(\mathrm{P}=0.018)$. A 2018 systematic review shows that herbal RCTs for the treatment of acne were more likely to report a higher number of the unique hCONSORT criteria (score=4.9) than those treating eczema (score, 3 ) or psoriasis (score, 2.9), although this was not statistically significant. ${ }^{12}$ Institutions that have dermatology training programs accredited by the Philippine Dermatological Society undergo regular research training and join research competitions, which may theoretically result in better quality of research reporting compared to non-accredited institutions.

There is a need to assess the quality of reporting of herbal dermatological RCTs in the Philippines to accurately determine the validity and reliability of data. Well-reported herbal RCTs will serve as a reliable source of evidence for continued traditional use and possibly, commercial production of herbal medicines.

\section{OBJECTIVE}

The study aimed to determine the quality of reporting of published herbal RCTs in dermatology in the Philippines.

\section{Specific objectives}

The specific objectives were to determine the mean reporting percentage of studies with the hCONSORT checklist and to determine the percentage of studies that reported each hCONSORT checklist item. 


\section{METHODS}

We structured this report according to the Preferred Reporting Items in Systematic Reviews and Meta-analysis (PRISMA 2009) checklist. $^{13}$

\section{Study protocol}

The study protocol of this review is available upon request from the authors. It was registered with the University of the Philippines Research Grants Administration Office (RGAO2018-0520) and the University of the Philippines College of Medicine Research Implementation and Development Office (GCS BS(Ana) 2018-001 (R-051TE)), prior to starting this review.

\section{Criteria for considering studies}

We planned to include studies that fulfilled the following criteria according to the type of participants, intervention, comparator, outcome, and study design:

1. Participants - any dermatological disease (for therapeutic trials) or normal dermatological condition (for disease prevention trials)

2. Intervention - any herbal medicine defined to include herbs, herbal materials, herbal preparations, and finished herbal products that contain as active ingredients parts of plants, or other plant materials, or combinations used for medicinal purposes and taken by ingestion, injection, or applied topically. In accordance with the definition of herbal medicine in hCONSORT, we excluded trials that used single compounds derived from plants or compounds based on specific constituents of plants. ${ }^{14}$ This is because most of the items asked in Item 4 (i.e., precise details of the interventions intended for each group and how and when they were actually administered) would not be applicable to the latter group of herbal products that are prepared from pure compounds obtained from manufacturers. Thus, trialists would not have had to perform the various steps needed to process raw plant material into the herbal product.

3. Comparator - any comparator

4. Outcome - any outcome

5. Study design - randomized controlled trials that were published as full reports and not just conference abstracts, and in any language.

\section{Searching for eligible studies}

We searched all published articles indexed in MEDLINE and CENTRAL (from inception to July 2018) using keywords 'Philippines' and 'dermatology OR skin OR cutaneous', and HERDIN (from inception to July 2018) using scientific names and common names of common herbs used in the Philippines (Appendix 2). Search strategy for PubMED is in Appendix 1. We also hand searched the table of contents of available issues (from inception up to 2017) of the Journal of the Philippine Dermatological Society (JPDS), Philippine Journal of Pediatrics (PJP), and Pediatric Infectious Disease Society of the Philippines Journal (PIDSPJ), the reference lists of included and excluded studies, and contacted known authors in the field.

\section{Study selection}

Two reviewers (RNFG and MCFB) independently screened the titles and abstracts of records and read the full texts of potentially relevant studies. We applied the eligibility criteria and only included studies that fulfilled all inclusion criteria.

\section{Data collection}

The following data items were collected using a data collection form:

1. General data: journal citation, professional status and institutional affiliation of main author, ethical approval, study funding, duration of study

2. Participants: setting, location, participants, disease, total number randomized

3. Herbal interventions: common name/binomial name/family name, part of plant, type of preparation, mode of delivery

\section{Reporting of hCONSORT 2006 checklist items}

The hCONSORT checklist contains 22 main items, but since some items had several aspects, we assessed them separately, and came up with 79 discrete study items for this review. Reporting was assessed as either 'yes', 'no', 'maybe' or 'not applicable' for each study item. We only considered a study to have fully reported an item if the assessment was 'yes'. Compliance was measured as the number of hCONSORT items that the study reported divided by the number of hCONSORT items (maximum possible number, 79). If the assessment to a study item was 'not applicable', this item was removed from the denominator for the number of items.

Pretesting of the data collection form was performed by extracting data from the first three reports retrieved and revising the form accordingly. Two sets of reviewers (RNFG and MCFB; RNFG and KMDL) independently extracted data and any disagreement was discussed to reach a consensus.

\section{Summary measures}

The primary outcome was defined as the mean reporting by included studies of the 79-item hCONSORT checklist. The secondary outcome was defined as the percentage of studies that reported each 79 study items.

\section{Synthesis of results}

A qualitative analysis was performed and we summarized results in a table by grouping the studies by several variables (e.g. disease, type of herb). 


\section{Risk of bias of studies}

We did not assess risk of bias of included studies since we aimed to analyze how well the RCTs were reported and not how well they were conducted.

\section{Data analysis}

Ordinal data were summarized with descriptive statistics using frequency and percentage distribution with Microsoft Excel [2016]. We also performed a quantitative analysis for the percentage of hCONSORT checklist items reported. We did post-hoc subgroup analysis according to institutional affiliation (whether an accredited dermatology training program by the Philippine Dermatological Society, PDS), indexing status (PubMED) of journal where published, year of publication (whether pre- or post-CONSORT 2006), type of herb, and type of disease using one-way ANOVA calculators. ${ }^{15,16}$ Our hypothesis was that papers published by PDS-accredited institutions, in PubMED-indexed journals and those published after CONSORT came out in 2006 will be more well-reported. We also hypothesized that Senna alata (akapulko) and Cocos nucifera (coconut oil), the most common types of herb used in the trials, would have better reporting quality.

\section{RESULTS}

\section{Study selection}

The search yielded 134 records. After eliminating duplicate titles and screening for title and abstract relevance according to our predetermined eligibility criteria, 55 potentially relevant articles were retrieved. Upon full-text review, we excluded 13 reports that failed to meet the inclusion criteria (single compound, ${ }^{17-19}$ quasi-randomized, ${ }^{20-24}$ controlled, ${ }^{25,26}$ single-arm trials, ${ }^{27}$ or non-herbal ${ }^{28,29}$ ) and one report awaiting classification, ${ }^{30}$ resulting in 41 studies that met the criteria for inclusion in this review (Figure 1).

\section{Study characteristics}

The details of each included study are in Appendix 3, and are summarized in Table 1. Majority of the studies were on infections, infestations, and bites (27/41,66\%), specifically scabies, dermatophytosis, and head lice. The most common families of herbs used were Fabaceae/Leguminosae (kakawati, akapulko) (9/41, 22\%), Arecaceae (coconut), Myrtaceae (eucalyptus, guava, tea tree) and Lamiaceae (lavender, lemon balm, peppermint, rosemary) (6/41, 12\% each). All herbal products were applied topically and around onefourth were cream preparations $(10 / 41,24 \%)$. Sample size in the trials ranged from 19 to 272 (mean, 76.9), with the greatest percentage (39\%) of trials having between 50 and 150 participants. Ethical approval was stated in around half of studies $(20 / 41,49 \%)$ while source of funding was only reported in six studies. Government institutions funded five studies, while a private institution funded one study. Two manufacturing companies provided the herbal products
Table 1. Summary of characteristics of included studies

\begin{tabular}{|c|c|}
\hline Category & No (\%) \\
\hline \multicolumn{2}{|l|}{ Disease } \\
\hline Infections/Infestations/Bites & $27(66)$ \\
\hline $\begin{array}{l}\text { Fungal skin infections (Dermatophytoses, Tinea } \\
\text { versicolor) }\end{array}$ & $8(20)$ \\
\hline Scabies & $7(17)$ \\
\hline Head lice & $5(12)$ \\
\hline Viral warts & $3(7)$ \\
\hline Bacterial skin infections & $2(5)$ \\
\hline $\begin{array}{l}\text { Others - Molluscum contagiosum, Mosquito bites } \\
\text { (1 each) }\end{array}$ & $2(5)$ \\
\hline Inflammatory/eczemas & $8(20)$ \\
\hline Acne vulgaris & $3(7)$ \\
\hline Atopic dermatitis & $2(5)$ \\
\hline Xerosis & $2(5)$ \\
\hline Seborrheic dermatitis & $1(2)$ \\
\hline Pigmentary & $3(7)$ \\
\hline Melasma & $3(7)$ \\
\hline $\begin{array}{l}\text { Misc - Basal cell carcinoma, Surgical wounds, Topical } \\
\text { anesthesia (1 each) }\end{array}$ & $3(7)$ \\
\hline \multicolumn{2}{|l|}{ Type of herb/Family } \\
\hline Fabaceae & $9(22)$ \\
\hline Akapulko & $6(15)$ \\
\hline Kakawati & $3(7)$ \\
\hline Arecaceae (Coconut) & $6(15)$ \\
\hline Myrtaceae & $6(15)$ \\
\hline Eucalyptus & $2(5)$ \\
\hline Guava & $2(5)$ \\
\hline Tea tree & $2(5)$ \\
\hline Asteraceae & $3(7)$ \\
\hline Sunflower & $2(5)$ \\
\hline Yarrow & $1(2)$ \\
\hline Lamiaceae & $6(15)$ \\
\hline Lavender & $2(5)$ \\
\hline Rosemary & $2(5)$ \\
\hline Others - Lemon balm, peppermint (1 each) & $2(5)$ \\
\hline Menispermaceae (Makabuhay) & $3(7)$ \\
\hline Rosaceae & $2(5)$ \\
\hline Apple & $1(2)$ \\
\hline Lady's mantle & $1(2)$ \\
\hline Solanaceae & $2(5)$ \\
\hline Siling haba & $1(2)$ \\
\hline Siling labuyo & $1(2)$ \\
\hline Theaceae (Green tea) & $2(5)$ \\
\hline Moringaceae (Malunggay) & $2(5)$ \\
\hline Caricaceae (Papaya) & $2(5)$ \\
\hline Others & $9(22)$ \\
\hline $\begin{array}{l}\text { Aloe (Asphodelaceae), cashew (Anacardiaceae), } \\
\text { citronella ('Cardiopteridaceae), ginger } \\
\text { (Zingiberaceae), lemongrass (Poaceae), mallow } \\
\text { (Malvaceae), mulberry (Moraceae), primrose } \\
\text { (Primulaceae), western dock (Polygonaceae) }\end{array}$ & 1 each \\
\hline
\end{tabular}




\begin{tabular}{lr}
\hline Professional status of main author & \\
\hline Resident trainee & $24(59)$ \\
Consultant/Practitioner & $6(15)$ \\
Medical student & $3(7)$ \\
Not stated & $8(20)$ \\
\hline Specialization of main author & $26(63)$ \\
\hline Dermatology & $7(17)$ \\
Pediatrics & $3(7)$ \\
Medical student & $3(7)$ \\
Family/Preventive Medicine & $1(2)$ \\
Obstetrics-Gynecology & $1(2)$ \\
Pharmacy & $27(66)$ \\
\hline Institutional affiliation of main author & $5(12)$ \\
\hline PDS-accredited & $3(7)$ \\
UERMMMC Department of Dermatology & $3(7)$ \\
JRRMMC Dept. of Dermatology & $3(7)$ \\
MMC Dept. of Dermatology & $3(7)$ \\
RITM Dept. of Dermatology & $3(7)$ \\
SCFI & $2(34)$ \\
STUH Dept. of Dermatology & $2(5)$ \\
UP-PGH Section of Dermatology & $2(5)$ \\
OMMC Dept. of Dermatology & \\
Others - DMC, EAMC (1 each) & $2(5)$ \\
\hline Non-PDS-accredited & \\
UERM College of Medicine & \\
DLSU Med Center Family Medicine & \\
Others - ADZU College of Medicine, DLS-STI Dept. & \\
$\quad$ of Ob-Gyne, IMH, MPI-MCP Dept. of Pediatrics, \\
OMMC Dept. of Pediatrics, SLMC Dept. of \\
Pediatrics, UERMMMC Dept. of Preventive and \\
$\quad$ Community Med, UST Pharmacy, VMMC Dept. of \\
Pediatrics, Not stated (1 each) & \\
\hline & \\
\hline
\end{tabular}

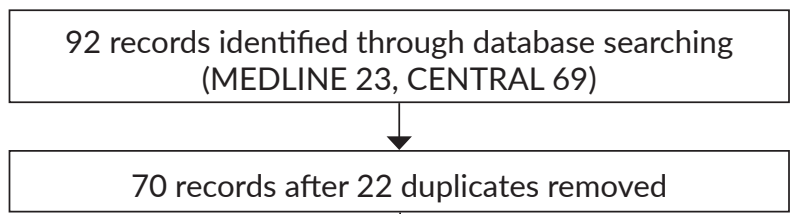

\begin{tabular}{lr}
\hline Journal of publication & \\
\hline Indexed & $11(27)$ \\
Acta Med Philipp & $2(5)$ \\
Dermatitis & $2(5)$ \\
Int J Dermatol & $2(5)$ \\
J Phil Med Assoc & $2(5)$ \\
Others - J Drugs Derm, J Pharmacol Pharmacother, & \\
$\quad$ Phil J Ob Gyn (1 each) & $3(7)$ \\
Non-indexed & $30(73)$ \\
J Phil Dermatol Soc & $15(37)$ \\
Phil J Ped & $4(10)$ \\
UERMMMC JHS & $4(10)$ \\
Fil Fam Phy & $2(5)$ \\
J Phil Soc Cut Med & $2(5)$ \\
Ped Infect Dis Soc Phil J & $2(5)$ \\
Phil J Microbiol Infect Dis & $1(2)$ \\
\hline Year of publication & $17(41)$ \\
\hline Pre-CONSORT 2006 & $1(2)$ \\
1980s & $2(5)$ \\
1990s & $14(34)$ \\
2000s & $21(51)$ \\
Post-CONSORT 2006 & $10(24)$ \\
$2000 s$ & $16(39)$ \\
$2010 s$ & $15(37)$ \\
\hline Sample size & \\
\hline >150 & $24(59)$ \\
<0-150 & \\
\hline & \\
\hline
\end{tabular}

Legend: PDS Philippine Dermatological Society; UERMMMC University of the East-Ramon Magsaysay Memorial Medical Center; STUH Santo Tomas University Hospital; JRRMMC Jose R. Reyes Memorial Medical Center; MMC Makati Medical Center; OMMC Ospital ng Maynila Medical Center; RITM Research Institute for Tropical Medicine; SCFI Skin and Cancer Foundation, Inc; UP-PGH University of the PhilippinesPhilippine General Hospital; DLSU De La Salle University; ADZU Ateneo de Zamboanga University; DLS De los Santos; DMC Davao Medical Center; EAMC East Avenue Medical Center; IMH Iloilo Mission Hospital; MPI-MCP Medical Center Paranaque; SLMC St. Luke's Medical Center; VMMC Veterans Memorial Medical Center

42 additional records identified through other sources

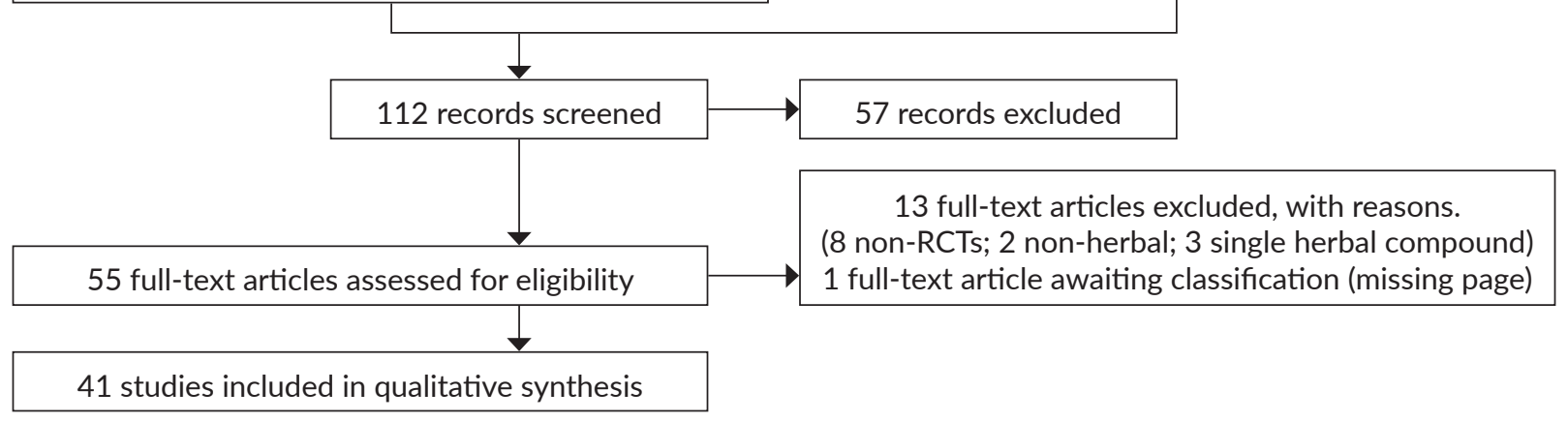

Figure 1. Study flow diagram. 
in two studies. Resident trainees were the main authors in majority of trials (24/41, 57\%), and belonged mostly to dermatology departments in institutions accredited by the Philippine Dermatological Society (27/41, 66\%). The top two institutions where the trials were conducted were the University of the East-Ramon Magsaysay Memorial Medical Center (8/41, 20\%) and Santo Tomas University Hospital (12\%). The trials were published in 14 journals, four of which were international publications, and eleven of which were PubMED-indexed. The most common journals where the studies were published were the Journal of the Philippine Dermatological Society (37\%), Philippine Journal of Pediatrics (10\%), and UERM Health Sciences Journal (10\%), which are local publications. The articles were published from 1983-2017, with a little over half (24/41, 59\%) after 2006, the year when hCONSORT was published.

\section{Percentage reporting of hCONSORT item of individual studies}

The mean percentage of reported hCONSORT checklist items was 39.6\% (SD 9.9; range 20.9, 60.0) and only a few studies $(7 / 41,17 \%)$ reported at least $50 \%$ of the hCONSORT checklist items (Table 2).

At least $50 \%$ of studies reported $31 / 79$ items, including identification of trial as randomized (1a) (95.1\%) and the type of preparation (1d) (95.1\%), in the title and abstract, and eligibility criteria (3a) (95.1\%) in the Methods section. Scientific background (2a) (85.4\%), rationale (2b) (80.5\%), including reasons with reference to herbal product $(2 \mathrm{c})$ (90.2\%), settings (3b) (87.8\%), common name of plant (4aiii) (80.5\%), appropriateness of outcome measures (6e) (87.8\%), and statistical methods (12a) (85.4\%) also scored high for reporting (Table 3 ).

In describing the herbal interventions in the Methods section (items $4 \mathrm{a}$ to $4 \mathrm{f}$ ), none of the studies provided complete details for the following: herbal medicinal product name, characteristics of the herbal product, dosage and quantitative description and qualitative testing. Specifically, no study reported on the family name of the plant, only one study reported on the status of registration with the Philippine Food and Drug Authority (Evangelista 2014), and method of authentication by a botanist from the Philippine Bureau of Plant Industry (Castillo 2013). In the latter study, the author also stated the specific geographic location (Angat, Bulacan) where the Tinospora cordifolia plant was sourced; the only author to report such. In addition, there was also poor reporting of type of extract (e.g. aqueous, alcoholic) (22\%), and part of plant used (37\%). On the other hand, specific herbal intervention details that were reported by more than $50 \%$ of studies aside from common name of plant $(81 \%)$ were: name of manufacturer (51\%), and type of product used (56\%). Majority of studies reported on the dosage (76\%) and duration (78\%) of administration but none on how dose and duration of treatment were determined (Table 3 ).
Table 2. Percentage distribution of reporting hCONSORT checklist (expanded 79-item)

\begin{tabular}{|c|c|}
\hline Study ID & $\begin{array}{l}\text { Reported items } \\
\text { No. (\%) }\end{array}$ \\
\hline 1. Abdujarak $2017^{31}$ & $19(27.5)^{* *}$ \\
\hline 2. Agero $2004^{33}$ & $28(38.4)^{\ddagger}$ \\
\hline 3. Aguilar $2004^{35}$ & $24(34.8)^{* *}$ \\
\hline 4. Alayon $2002^{37}$ & $32(46.4)^{* *}$ \\
\hline 5. Alvin $2011^{39}$ & $36(50.7)^{* * * *}$ \\
\hline 6. Ancheta $2004^{41}$ & $23(31.5)^{\ddagger}$ \\
\hline 7. Bañez $1999^{43}$ & $27(38.0)^{* * * *}$ \\
\hline 8. Banzon $2008^{45}$ & $31(43.1)^{\dagger}$ \\
\hline 9. Buensalido $2011^{47}$ & $31(43.7)^{* * * *}$ \\
\hline 10. Cabillos $2003^{49}$ & $27(38.0)^{* * * *}$ \\
\hline 11. Castillo $2013^{51}$ & $33(45.8)^{\dagger}$ \\
\hline 12. Concepcion $1999^{53}$ & $23(33.3)^{* *}$ \\
\hline 13. Cue $2010^{55}$ & $28(39.4)^{* * * *}$ \\
\hline 14. De Las Alas $2014^{57}$ & $39(52.7)^{\S}$ \\
\hline 15. De Leon-Godinez $2011^{59}$ & $23(31.9)^{\dagger}$ \\
\hline 16. De Leon-Pandanan $2002^{61}$ & $23(33.3)^{* *}$ \\
\hline 17. Despuig $2016^{63}$ & $22(31.4)^{* * *}$ \\
\hline 18. Dizon $2013^{65}$ & $45 / 75(60.0)^{\pi}$ \\
\hline 19. Dofitas $2001^{67}$ & $43(59.7)^{\dagger}$ \\
\hline 20. Dumlao $2002^{68}$ & $18(25.0)^{\dagger}$ \\
\hline 21. Evangelista $2014^{70}$ & $36(48.6)^{\S}$ \\
\hline 22. Francisco-Diaz $2004^{32}$ & $22(31.4)^{* * *}$ \\
\hline 23. Gan $2003^{34}$ & $25(36.2)^{* *}$ \\
\hline 24. Guillano $2005^{36}$ & $37(51.4)^{\dagger}$ \\
\hline 25. Hau $2008^{38}$ & $32(45.1)^{\dagger}$ \\
\hline 26. Lagunzad $2013^{40}$ & $30(41.1)^{\ddagger}$ \\
\hline 27. Lisdyanti $2011^{42}$ & $23(31.9)^{\dagger}$ \\
\hline 28. Lombos $2015^{44}$ & $21(30.0)^{* * *}$ \\
\hline 29. Martinez $2014^{46}$ & $29(40.8)^{\ddagger}$ \\
\hline 30. Mendoza $2014^{48}$ & $15(21.4)^{* * *}$ \\
\hline 31. Moreno $2016^{50}$ & $28(39.4)^{* * * *}$ \\
\hline 32. Naagas $2013^{52}$ & $36(51.4)^{* * *}$ \\
\hline 33. Ong-Salvador $2000^{54}$ & $24(33.3)^{\dagger}$ \\
\hline 34. Perez-Chua $2012^{56}$ & $29(40.8)^{* * * *}$ \\
\hline 35. Ramiro $2014^{58}$ & $30(41.7)^{\dagger}$ \\
\hline 36. Rivera $1983^{60}$ & $14(20.9)^{*}$ \\
\hline 37. Sayo-Bondoc $2016^{62}$ & $38(54.3)^{* * *}$ \\
\hline 38. Tavanlar-Amado $2014^{64}$ & $42(57.5)^{\ddagger}$ \\
\hline 39. Uy $2003^{66}$ & $27(38.6)^{* * *}$ \\
\hline 40. Verallo-Rowell 2008 & $25(34.7)^{\dagger}$ \\
\hline 41. Yoro $2005^{69}$ & $19(27.1)^{* * *}$ \\
\hline Mean (SD) & $39.6(9.9)$ \\
\hline
\end{tabular}

Note: Denominator is less than 79 due to non-inclusion of items not applicable to the study

${ }^{*} n=67, " n=69,{ }^{* * *} n=70, * * n=71,{ }^{\dagger} n=72,{ }^{\ddagger} n=73,{ }^{\circledR} n=74,{ }^{\top} n=75$

In bold font are studies with more than 50\% reported checklist items 
Table 3. Percentage distribution of studies $(\mathrm{N}=41)$ that reported individual hCONSORT 2006 checklist items

1. Title and abstract

1.a. How participants were allocated to interventions (e.g. "random allocation, "randomized" or "randomly assigned"

1.b. Either the title or abstract, or both should state the herbal medicinal product's Latin binomial

1.c. the part of the plant used

7 (17.1)

1.d. and the type of preparation

39 (95.1)

2. Introduction

Background

2.a. Scientific background

2.b. and explanation of rationale

2.c. Including a brief statement of reasons for the trial with reference to the specific herbal medicinal product being tested and...

2.d. If applicable, whether new or traditional indications are being investigated.

3. Methods/Participants

3.a. Eligibility criteria for participants

3.b. Settings and...

3.c. locations where the data were collected

3.d. If a traditional indication is being tested, a description of how the traditional theories and concepts were maintained. For example, participant inclusion criteria should reflect the theories and concepts underlying the traditional indication.

\section{Methods/Interventions}

4.a. Herbal medicinal product name

4.a.i. The Latin binomial name together with botanical authority

4.a.ii. and family name for each herbal ingredient;

4.a.iii. common name(s) should also be included

4.a.iv. The propriety product name (i.e. brand name) or the extract name (e.g. Egb-761)

4.a.v. and the name of the manufacturer of the product

4.a.vi. Whether the product used is authorized (licensed, registered) in the country in which the study was conducted

4.b. Characteristics of the herbal product

4.b.i. The part(s) of plant used to produce the product or extract.

4.b.ii. The type of product used (e.g. raw [fresh or dry], extract)

4.b.iii. The type and concentration of extraction solvent used (e.g. $80 \%$ ethanol, $100 \% \mathrm{H} 2 \mathrm{O}, 90 \%$ glycerine, etc.) and the ratio of herbal drug to extract (e.g., 2 to 1 )

4.b.iv. The method of authentication of raw material (i.e. how done and by whom)

4.b.v. and the lot number of the raw material

4.b.vi. State if a voucher specimen (i.e., retention sample) was retained and,

4.b.vii. if so, where it is kept or deposited, and the reference number

4.c. Dosage regimen and quantitative description

4.c.i. The dosage of the product,

4.c.ii. the duration of administration and

4.c.iii. how these were determined product constituents, both native and added, per dosage unit form. Added materials, such as binders, fillers, and other excipients; e.g., 17\% maltodextrin, 3\% silicon dioxide per capsule, should also be listed.

4.c.v. For standardized products, the quantity of active/marker constituents per dosage unit form

4.d. Qualitative testing

4.d.i. Product's chemical fingerprint

4.d.ii. and methods used (equipment and chemical reference standards)

4.d.iii. and who performed the chemical analysis (e.g. the name of the laboratory used);

4.d.iv. whether a sample of the product (i.e. retention sample) was retained

4.d.v. and if so, where it is kept or deposited

4.d.vi. Description of any special testing/purity testing (e.g., heavy metal or other contaminant testing) undertaken,

4.d.ix. Standardization: what to standardize (e.g., which chemical components of the product) 
4.e. Placebo/control group The rationale for the type of control/placebo used

4.f. Practitioner A description of the practitioners (e.g., training and practice experience) that are part of the intervention

6. Outcomes

6.a. Completely defined pre-specified primary outcome measures

6.b. Completely defined pre-specified secondary outcome measures

6.c. including how and when they were assessed

6.d. when applicable, any methods used to enhance the quality of measurements (e.g., multiple observations, training assessors)

6.e. Outcome measures should reflect the intervention and indications tested considering, where applicable, underlying theories and concepts

\section{Sample size}

7.a. How sample size was determined

7.b. When applicable, explanation of any interim analyses and stopping guidelines

8. Randomization/Sequence generation

8.a. Method used to generate the random allocation sequence

8.b. Type of randomization; details of any restriction (such as blocking and block size)

9. Randomization/Allocation concealment mechanism

Mechanism used to implement the random allocation sequence (such as sequentially numbered containers); describing any

$16(39.0)$ steps taken to conceal the sequence until interventions were assigned

10. Randomization - Implementation

10.a. Who generated the random allocation sequence,

10.b. who enrolled participants,

10.c. and who assigned participants to interventions

11.a. Whether or not participants, those administering the interventions, and those assessing the outcomes were blinded to group assignment

11.b. When relevant, how the success of blinding was evaluated

12. Statistical Methods

12.a. Statistical methods used to compare groups for primary and secondary outcomes

12.b. Methods for additional analyses, such as subgroup analyses and adjusted analyses

13. Results

Participant flow

13.a. For each group, the numbers of participants who were randomly assigned,

13.b. received intended treatment,

13.c. and were analyzed for the primary outcome

13.d. For each group, losses and exclusions after randomization, together with reasons

Dates defining the periods of recruitment and follow up

15. Baseline Data

15.a.i. A table showing baseline demographics

$30(73.2)$

15.a.ii. and clinical characteristics for each group

$26(63.4)$

15.a.iii. including concomitant medications,

15.a.iv. herbal, and

15.a.v. complementary medicine use

For each group, number of participants (denominator) included in each analysis and whether the analysis was by original assigned groups

17. Outcomes and estimation

For each primary and secondary outcome, results for each group, and the estimated effect size and its precision (such as 95\% confidence interval)

18. Ancillary analyses

Results of any other analyses performed, including subgroup analyses and adjusted analyses, distinguishing pre-specified from exploratory 
20. Discussion

Interpretation

20.a.i. Interpretation of results, taking into account study hypotheses, sources of potential bias or imprecision and the dangers associated with multiplicity of analyses and outcomes

20.a.ii Interpretation of the results in light of the product and

$18(43.9)$

20.a.iii. Interpretation of the results in light of the dosage regimen used

21. Generalisability

21.a. Generalisability (external validity, applicability) of the trial findings

21.b. Where possible, discuss how the herbal product and dosage regimen used related to what is used in self-care and/or practice.

22. Overall evidence

General interpretation of the results in the context of current evidence. Discussion of the trial results in relation to trials of other available products.

Legend: ${ }^{*} n=0 ;{ }^{* *} n=10 ;{ }^{* * *} n=5 ;{ }^{* * * *} n=8$ (other studies excluded since sub-item was not applicable)

Table 4. Subgroup analysis of percentage of reported hCONSORT checklist items based on institution, journal, and year published

\begin{tabular}{lccc}
\hline Study variable & Mean (SD) & F-stat & P-value* \\
Institution & & 7.37109 & 0.75246 (NS) \\
$\quad$ PDS-accredited & $42.54(10.04)$ & & \\
$\quad$ Not PDS-accredited & $34.41(7.59)$ & & \\
\hline Journal & & 0.00003 & 0.999 (NS) \\
$\quad$ PubMED-indexed & $39.55(13.0)$ & & \\
$\quad$ Not PubMED-indexed & $39.57(8.85)$ & & \\
\hline Year of publication & & 3.28581 & 0.7694 (NS) \\
$\quad$ Pre-hCONSORT 2006 & $36.31(9.42)$ & & \\
Post-hCONSORT 2006 & $41.87(9.85)$ & & \\
\hline
\end{tabular}

PDS Philippine Dermatological Society; *Using One-way ANOVA; NS Not significant

Characteristics of the herbal medicinal products were also poorly reported with no information from any study on the following: lot number of raw material (4bii), whether voucher specimen was retained (4bvi), where it is kept, and reference number (4bvii). Qualitative testing details were also poorly reported, with only one study that reported on the method used for chemical fingerprint (4dii) (i.e. thin layer chromatography), ${ }^{67}$ although the actual chemical fingerprint (4di) and information on a retention sample (4diii to iv) were not elaborated. The same study was also the only one which reported on purity testing methods (4dvi) for akapulko lotion (i.e. total ash content, acidinsoluble ash, foreign organic matter). However, it did not state if unwanted components were removed and how. No study reported on standardization details, and there was no information on whether the herbal interventions they tested were on standardized products.

Post-hoc subgroup analyses showed no significant difference in percentage of reported hCONSORT items between groups based on accreditation of the institution of main author as a dermatology training program of the Philippine Dermatological Society (PDS), the status of PubMED indexing of the journal or the timing of
Table 5. Subgroup analysis of percentage distribution of reported hCONSORT checklist items based on type of herb

\begin{tabular}{lcrccc} 
Type of herb & N & Mean (SD) & F-stat & Df & P-value \\
Akapulko & 6 & $37.5(9.0)$ & 0.59 & 10 & 0.8 \\
Coconut & 6 & $43.3(9.4)$ & & & \\
Kakawati & 3 & $39.4(5.9)$ & & & \\
Makabuhay & 3 & $44.0(16.2)$ & & & \\
Green tea & 2 & $34.1(1.1)$ & & & \\
Guava & 2 & $46.0(20.6)$ & & \\
Lavender, rosemary, & 2 & $34.6(2.3)$ & & \\
$\quad$ eucalyptus & & & & \\
Malunggay & 2 & $34.7(8.6)$ & & \\
Papaya & 2 & $44.0(6.5)$ & & \\
Sili & 2 & $35.0(4.3)$ & & \\
Tea tree & 2 & $31.2(15.0)$ & & \\
\hline Total & 32 & & & \\
\hline
\end{tabular}

Note: Herb group with only one study $(n=9)$ cannot be entered into one-way ANOVA analysis

Table 6. Percentage distribution of reported hCONSORT checklist items and One-way ANOVA analysis based on disease

\begin{tabular}{lrrrrc} 
Disease & N & Mean (SD) & F-stat & Df & P-value \\
Dermatophytoses & 8 & $41.0(9.8)$ & 0.78 & 7 & 0.62 \\
Scabies & 7 & $34.4(9.0)$ & & & \\
Head lice & 5 & $38.4(3.9)$ & & & \\
Warts & 3 & $41.5(13.9)$ & & & \\
Acne & 3 & $31.7(4.4)$ & & & \\
Melasma & 3 & $35.0(14.8)$ & & \\
Bacterial infections & 2 & $41.0(8.9)$ & & \\
Atopic dermatitis & 2 & $34.7(8.6)$ & & \\
Xerosis & 2 & $44.9(9.2)$ & & & \\
\hline Total & 35 & & & &
\end{tabular}

Note: Disease group with only one study $(n=6)$ cannot be entered into one-way ANOVA analysis

publication of the study in relation to hCONSORT 2006 publication (Table 4).

There was no significant difference between different types of herbs (F-stat $=0.59 ; \mathrm{P}=0.8$ ) (Table 5), and disease (F-stat $=0.78 ; \mathrm{P}=0.62)$ (Table 6). 


\section{DISCUSSION}

Our review included 41 herbal RCTs that were mostly on infestations, infections, and bites, while the 2011 systematic review of three major databases had psychology as the major topic (112/406) and only 9 on dermatology. ${ }^{7}$ This highlights the burden of infectious diseases that is still prevalent in tropical and low-income countries such as the Philippines, compared to higher-income countries where psychological disorders are more predominant. The most commonly studied herbs in our review were akapulko and coconut ( $\mathrm{n}=6$ each) which were not studied in any of the previous systematic reviews. Ginkgo ( $\mathrm{n}=99 / 406$; Asean Plus Six countries only) and ginger $(n=36 / 71$; no geographic restriction $)^{7}$ were the most common herbs in previous systematic reviews. This finding indicates the promising potential for akapulko and coconut in the ASEAN and global market.

Our findings suggest that the published RCTs on treatment and prevention of dermatological diseases involving herbal interventions in the Philippines poorly reported checklist items suggested by the hCONSORT guidelines. The mean reporting rate was only $39.6 \%$ (SD 9.9), and only $15 \%$ of studies in our review reported at least $50 \%$ of the hCONSORT checklist items. Our results are similar to the 2011 systematic review of 11 top selling herbal products in the USA (mean compliance, $38 \%),{ }^{7}$ and the 2018 review that included herbal products for acne, atopic dermatitis, or psoriasis (15\% of studies reported less than half of hCONSORT items). ${ }^{8}$ On the other hand, our findings contrast with the 2015 systematic review that reported more than $80 \%$ of included studies that complied to more than $50 \%$ of the items in the hCONSORT checklist. ${ }^{9}$ Since this 2015 review included RCTs for 20 registered herbal products in Thailand, the high reporting compliance may be a reflection of the robust herbal medicine industry and integration into their national formulary. In contrast, the Philippines currently has only three herbal products (lagundi [Vitex negundo], sambong (Blumea balsamifera], tsaang gubat [Ehretia microphylla]) in the Philippine National Drug Formulary, ${ }^{71}$ and none is indicated for skin disease.

Poor reporting of details of the herbal intervention such as the family name and binomial name in the Abstract, which are more internationally used, will make it difficult for the scientific community to recognize the herbs. Some researchers did not include these specific details for herbal interventions in the Abstract, resulting in a decreased chance for these articles to be indexed and retrieved. To facilitate access to herbal medicine literature, hCONSORT recommends the inclusion of the product's Latin binomial, part of the plant used and type of preparation in the title and abstract of the article. It is also possible that researchers failed to mention the part of the plant used because they assume it is public knowledge (e.g. coconut oil, papaya latex, etc.) or that it is not relevant to know. However, it is a factor that may change the quality of the herbal medicine and eventual efficacy and safety, and thus, is important to state explicitly.

In the Methods section, none of our included studies provided complete information on the herbal medicinal product name, characteristics of the herbal product, dosage regimen and quantitative description and qualitative testing. This information is needed to have a comprehensive knowledge on the product to allow comparison of its efficacy and safety to other products. Seventy-eight percent of the studies did not provide the Latin binomial together with the botanical authority, and none of the studies provided the family name of the plant used. Our findings are similar to the previous 2015 systematic review, where studies also did not provide botanical authority and family name, and $62 \%$ of studies did not provide the Latin binomial name. ${ }^{9}$ Complete reporting of the herbal medicinal product name in future researches is necessary to ensure replicability of test results. An important information that was not included in hCONSORT but was reported in one included study ${ }^{51}$ is the geographic location where the plant was harvested. Agricultural production and collection details are essential since different locations have varying climates, soil conditions, and agricultural practices (WHO 2000). ${ }^{14}$ In particular, there were several items that were never reported (e.g., voucher specimen of raw material, product's chemical fingerprint, retention sample of product, removal of unwanted components), which is similar to the previous 2011 systematic review. ${ }^{7}$

None of the studies stated using a standardized herbal product, and this may be because the products used in traditional practice are not pure compounds and active constituents have not been identified. Compared to this finding, the previous systematic reviews showed that $33 \%^{12}$ to $51 \%^{7}$ of studies reported on standardization details. This may be explained by the more developed herbal industry in higher-income countries, and is especially relevant in resource-limited countries like the Philippines where lack of access to costly drugs may be bridged by readily available traditional medicinal plants. None of the studies provided adequate information on how herbal product dosage was derived even when pre-clinical studies were present. Dosing implications were considered only after the study was done. These are missed opportunities to have carried out well-planned protocols with efficient use of resources. In a previous systematic review, $70 \%$ of the assessed articles also did not provide the recommended information on dosing regimen and cited that even the rationale for dosing and frequency of application of topical agents such as steroids has been limited. ${ }^{8}$

In the Discussion, less than $5 \%$ of the studies in this review discussed generalizability of results that would have elucidated on the applicability of the study findings under different conditions. This finding contrasts with previous systematic review that showed $67 \%$ of studies reported on 
generalizability, although only $14 \%$ discussed this in relation to self-care and practice. ${ }^{7}$ This would have greatly aided in providing practical recommendations on the use of the herbal product for other groups of individuals, or another product formulation being used in practice or self-care. More than $60 \%$ of the trials did not compare their results to other trials or interpret their results in the context of current evidence. This may have been due to lack of previous clinical trials on the herbal product, especially if the trials were pilot studies. Lack of access to full reports of previous studies on the topic, especially for studies published before the digital age, may have been a limitation. Hopefully, with improved indexing specificity of future herbal intervention studies, herbal literature will be easily accessed by researchers working on the same product.

In general, the quality of most of the studies in our review could still be increased by improved reporting of items other than those specific to herbal interventions, such as clearly stating the primary and secondary outcome measures, describing the placebo used, and specifying the type of randomization.

The reporting rate of included studies did not significantly differ between groups as to type of institution, status of indexing of journal, and the year of publication. Poor reporting of hCONSORT checklist items across institutions, journals, and through the decades may be due to the: 1) lack of awareness on the existence of hCONSORT, 2) lack of training of researchers in the dermatology residency programs on the use of hCONSORT and 2) lack of enforcement of hCONSORT guidelines by research mentors and journal editors. Likewise, the type of herb and disease did not affect the quality of reporting of our included studies. This differs from a previous systematic review where RCTs that used North American ginseng showed significantly higher quality than other herbal RCTs. ${ }^{7}$

We only hand searched three local journals so we may have missed some other relevant RCTs in journals that we did not have direct access. All studies were on topical herbal products so that our findings are not generalizable to oral herbal products, considering the widespread intake of whitening pills. In addition, we did not assess the risk of bias in these studies, as well as the magnitude and precision of the treatment effects of the herbal interventions compared with their comparator drugs. These are also important aspects of determining quality that will provide an evidence base for rational use of herbal products.

\section{CONCLUSION}

Published herbal RCTs in dermatology from the Philippines are poorly reported according to the hCONSORT criteria. The hCONSORT guideline needs to be widely disseminated to researchers working on herbal interventions for dermatologic diseases, and compliance to the hCONSORT checklist should be required for submitted manuscripts of herbal RCTs by journal editors. These steps will ensure quality protocols, data gathering, and data presentation to enable the promotion and practice of evidence-based herbal medicine in the country.

\section{Statement of Authorship}

All authors participated in data collection and analysis, and approved the final version submitted.

\section{Author Disclosure}

All authors declared no conflict of interest.

\section{Funding Source} Society.

This paper was funded by the Philippine Dermatological

\section{REFERENCES}

1. Philippines. Republic Act No. 8423. Traditional and Alternative Medicine Act (TAMA) of 1997 [Internet]. 1997 [cited 2018 Jul]. Available from http://pitahc.gov.ph/?page_id $=147$.

2. PCHRD. Annual Report 1995 [Internet]. 1995 [cited 2018 Sep]. Available from http://www.pchrd.dost.gov.ph/index.php/2uncategorised/3218-annual-report-1995.

3. Genuino R. Content Analysis of Herbal Research Studies in the Journal of the Philippine Dermatological Society (1992-2017) (E-Poster, Annual Convention of the Philippine Dermatological Society, EDSA Shangrila,Mandaluyong, Philippines; November 7-9, 2018). 2018.

4. Lefebvre C, Manheimer E. Chapter 6: Searching for Studies. In: Higgins JPT, Green S (Editors). Cochrane Handbook for Systematic Reviews of Interventions Version 5.1.0 (Updated March 2011). The Cochrane Collaboration; 2011.

5. EQUATOR. Enhancing the QUAlity and Transparency Of health Research (EQUATOR) Network.

6. Gagnier JJ, Boon H, Rochon P, Moher D, Barnes J, Bombardier C; CONSORT Group. Reporting randomized, controlled trials of herbal interventions: An elaborated CONSORT Statement. Ann Intern Med. 2006; 144(5):364-7

7. Gagnier JJ, Moher D, Boon H, Beyene J, Bombardier C. Randomized controlled trials of herbal interventions underreport important details of the intervention. J Clin Epidemiol. 2011;64(7):760-9. doi:10.1016/ j.jclinepi.2010.10.005.

8. Ornelas J, Routt E, Kallis P, Lev-Tov H. Use of the hCONSORT criteria as a reporting standard for herbal interventions for common dermatoses: a systematic review. Br J Dermatol. 2018; 178(4):889-96. doi:10.1111/bjd.16256.

9. Pratoomsoot C, Sruamsiri R, Dilokthornsakul P, Chaiyakunapruk N. Quality of reporting of randomised controlled trials of herbal interventions in ASEAN plus six countries: A systematic review. PLoS One. 2015; 10(1):e108681. doi:10.1371/journal.pone.0108681.

10. Rochon PA, Bero LA, Bay AM, Gold JL, Dergal JM, Binns MA, et al. Comparison of review articles published in peer reviewed and throwaway journals. JAMA. 2002; 287(21):2853-6.

11. Moher D, Jones A, Lepage L; CONSORT Group (Consolidated Standards for Reporting of Trials). Use of the CONSORT statement and quality of reports of randomized trials: a comparative before-andafter evaluation. JAMA. 2001; 285(15):1992-5.

12. Ornelas J, Routt E, Kallis P, Lev-Tov H. Use of the hCONSORT criteria as a reporting standard for herbal interventions for common dermatoses: a systematic review. Br J Dermatol. 2018;178(4):889-96. doi:10.1111/bjd.16256.

13. Moher D, Liberati A, Tetzlaff J, Altman DG; PRISMA Group. Preferred reporting items for systematic reviews and meta-analyses: The PRISMA statement. PLoS Med. 2009;6(7):e1000097. doi:10.1371/ journal.pmed.1000097. 
14. World Health Organization. General Guidelines for Methodologies on Research and Evaluation of Traditional Medicine. WHO-Geneva. 2000; 1:1-74. doi:WHO/EDM/TRM/2000.1.

15. ICalcu. One-way ANOVA and Tukey's HSD Calculator [Internet]. iCalcu.com. [cited 2018 Sep]. Available from https://www.icalcu.com/ stat/anova-tukey-hsd-calculator.html.

16. Sanders J. Good Calculators [Internet]. 2018 [cited 2018 Sep]. Available from https://goodcalculators.com/one-way-anova-calculator/.

17. Abraham ER, Verallo-Rowell VM. Safety and efficacy of monolaurin, a coconut oil extract, versus ethyl alcohol in rinse-free hand antiseptic gels on healthcare personnel's hands and microbial isolates. J Phil Dermatol Soc. 2001; 10(2):90-9.

18. Dim-Jamora K, Verallo-Rowell V. 2\% Monolaurin cream and $2 \%$ mupirocin cream in the treatment of superficial bacterial skin infections: A double blind randomized controlled clinical trial. J Phil Dermatol Soc. 2006; 15(2):31-6.

19. Handog EB, Galang DA, De Leon-Godinez MA, Chan GP. A randomized, double-blind, placebo-controlled trial of oral procyanidin with vitamins $\mathrm{A}, \mathrm{C}, \mathrm{E}$ for melasma among Filipino women. Int J Dermatol. 2009; 48(8):896-901.

20. Felicen GB, Felix ACA, Fermo TAV, et al. A comparative study on the cost-effectiveness of $50 \%$ Gliricidia sepium (kakawati) ointment and $50 \%$ sulfur ointment in treating patients with scabies in Area III, Payatas, Quezon City. UERMMMC J Heal Sci. 2003; 6(1):7-14.

21. Nagbuya-Cebrian P, Regalado-Morales E, Dizon J. A randomized double blind clinical trial on the efficacy and safety of tea tree oil in the treatment of tinea corporis. J Phil Soc Cut Med. 2003; 4(1):61-70.

22. Salazar NP, Sabordo NT, Romero RC, Montalban CS, Acacio MR, Tarrayo MG, et al. Tinospora rumphii Boerl. (Makabuhay) in the treatment of scabies. Phil J Microbiol Infect Dis. 1987; 16(1):25-9.

23. Sta. Ana MLD, Dayrit JF, Teodosio G, Gabriel MTG. A preliminary study on the mosquito repellent effect of tea tree (Melaleuca alternifolia) oil. J Phil Dermatol Soc. 2005;14(1):33-7.

24. Ty JT, Gutierrez SB, Lo-letran E, Design S, Out-patient D. Phase I and Phase II clinical trial on the safety and efficacy of calamansi (Citrus microcarpa Bunge) pulp extract cream in the treatment of tinea versicolor. J Phil Dermatol Soc. 2008; 17(2):22-6.

25. King-Caumban CM, Paliza AC. Tea soaks for palmoplantar hyperhidrosis. J Phil Dermatol Soc. 1996; 5(1):8-17.

26. Sembrano-Ilagan MA, de Dios-Torralba L, del Castillo-Solevilla R. Clinical evaluation of $\mathrm{CMC}-10$ in the treatment of localized primary pyogenic skin diseases. J Phil Dermatol Soc. 1994; 3(1):26-30.

27. Salcedo-Rubio E, Yao-Dy N, Barcelona-Tan J, Abad-Venida ML. An open clinical trial on the efficacy and safety of $10 \%$ aged garlic (Allium sativum) cream in the treatment of molluscum contagiosum. J Phil Dermatol Soc. 2003; 12(1):28-33.

28. Gicaro GAT, Gonzales NM, Yap CB, Batac MCR, Cellona CV. The efficacy of topically applied honey compared to solcoseryl $10 \%$ jelly in the treatment of venous leg ulcers: A randomized, observerblind controlled clinical trial. J Phil Dermatol Soc. 2006; 15(2):22-9.

29. Ledesma TG V, Casal-Panis EG, Senador LR, Dayrit JF, Gabriel MTG. A randomized, double-blind, controlled trial on the safety and efficacy of bee propolis $5 \%$ ointment versus clobetasol propionate $0.05 \%$ ointment for lichen simplex chronicus. J Phil Dermatol Soc. 2017; 26(2):30-5.

30. Angeles CB, Katiyar SK, Ampil IDI, Arcilla B. Prevention of UVBinduced erythema with topical treatment of green tea extract: a randomized, placebo and active controlled clinical trial.J Phil Dermatol Soc. 2004; 13(1):8-15.

31. Abdurajak B. Moringa oleifera (malunggay) leaves extract topical gel vs $2.5 \%$ benzoyl peroxide as treatment for acne vulgaris: A randomized controlled trial. Phil J Ped. 2017; 64(2):12-7.

32. Francisco-Diaz $M$, Cataluna $M$, dela Cruz M, Verallo-Rowell V. A double-blind randomized placebo controlled trial on the efficacy and safety of botanical extract (Gigawhite 5\% solution) in the treatment of melasma. J Phil Dermatol Soc. 2004; 13(1):18-23.

33. Agero AL, Verallo-Rowell VM. A randomized double-blind controlled trial comparing extra virgin coconut oil with mineral oil as a moisturizer for mild to moderate xerosis. Dermatitis. 2004; 15(3):109-16.
34. Gan-Wong J, Salcedo-Rubio EC, Barcelona-Tan J. Comparison between $3 \%$ green tea (Camellia sinensis) extract in cream and $4 \%$ benzoyl peroxide cream in the treatment of acne vulgaris: A randomized, double-blind clinical trial. J Phil Soc Cut Med. 2003; 4(1):83-95.

35. Aguilar D, Almerol I, Alejandre J, et al. A randomized double blinded experimental study on the efficacy of $75 \%$ aqueous akapulko (Cassia alata) solution in the treatment of Tinea pedis using $1 \%$ clotrimazole (canesten). UERMMMC J Heal Sci. 2004; 7(1):45-9.

36. Guillano GJ, Alabado KLP. A randomized, double-blind, clinical trial on the effectiveness and safety of $50 \%$ Gliciridia sepium (Kakawate/ madre de cacao) ointment compared with $2 \%$ miconazole ointment in the treatment of tinea corporis and tinea cruris (a pilot study). J Phil Dermatol Soc. 2005; 14(2):15-22.

37. Alayon JF, Alcantara RS. Efficacy and acceptability of $80 \%$ akapulco (Cassia alata) Iotion in the treatment of scabies. Fil Fam Phy. 2002; 40(3):87-94.

38. Hau CS, Tianco EA V. The antidermatophytic activity of Zingiber officinale (ginger): In vitro study of ginger rhizome extract in ethanol using various dermatophytes and Candida albicans, and double-blind, randomized controlled trial comparing commercially prepared ginger rhiz. J Phil Dermatol Soc. 2008; 17(1):14-22.

39. Alvin G, Catambay N, Vergara A, Jamora MJ. A comparative study of the safety and efficacy of $75 \%$ mulberry (Morus alba) extract oil versus placebo as a topical treatment for melasma: A randomized, single-blind, placebo-controlled trial. J Drugs Dermatol. 2011; 10(9):1025-31.

40. Lagunzad JC, Ismael DK. An assessor-blind, randomized controlled trial on the efficacy and safety of apple cider vinegar vs. salicylic-lactic acid solution in the treatment of common warts. J Phil Dermatol Soc. 2013; 22(1):23-8.

41. Ancheta BM, Ang LT, Anorico LPS, et al. A preliminary experimental study on the efficacy of kakawati (Gliricidia sepium) soap together with the kakawati ointment preparation as compared to the use of the kakawati ointment alone in the treatment of scabies. UERMMMC J Heal Sci. 2004; 7(1):38-44.

42. Lisdyanti M, Baliton RWG, Bautista-Zamora B. The effect of topical mupirocin ointment versus Aloe vera with Vitamin $\mathrm{E}$ cream on post-surgical wound healing: A randomized-double blind placebo controlled trial. Phil J Obs Gynecol. 2011;35(1):19-31.

43. Banez JA, Nazareno RC, Medel RB. Clinical trial on the effectiveness of Gliricidia sepium (Kakawati) in treating patients with scabies in the Antipolo CBHP. Phil J Microbiol Infect Dis. 1999; 28(4):147-153.

44. Lombos-Serondo MRB, Cuizon-Borromeo LCL, Victa JJ, Lavadia MAM. A pilot study to compare the effects of salicylic acid $16.5 \%$ + lactic acid $16.5 \%$ solution and Melaleuca alternifolia (Tea Tree) oil on the resolution rates of verruca vulgaris. J Philipp Med Assoc. 2016; 94(1):86-101.

45. Banzon JCD, Amor D, Feliciano V. A randomized, double-blind, placebo-controlled study on the efficacy and safety of 50\% and $75 \%$ capsaicin ointment as compared to a topical local anesthetic cream as a topical anesthetic agent. J Phil Dermatol Soc. 2008; 17(1):23-30.

46. Martinez RED, Samson JP. A doube blind randomized clinical trial on the efficacy of citronella shampoo versus $5 \%$ permethrin lotion in the treatment of head lice infestation. Ped Infect Dis Soc Phil J. 2014; 15(2):2-9.

47. Buensalido JS, Dimagiba MTE. The efficacy and safety of $1.5 \%$ Carica papaya latex cream compared to $2 \%$ ketoconazole cream and vehicle in the treatment of tinea corporis: A randomized, double blind, controlled trial. J Phil Dermatol Soc. 2011; 20(1):15-20.

48. Mendoza CG, Singzon IA, Handog EB. A randomized, double-blind, placebo-controlled clinical trial on the efficacy and safety of 3\% Rumex occidentalis cream versus $4 \%$ hydroquinone cream in the treatment of melasma among Filipinos. Int J Dermatol. 2014; 53(11):1412-6. doi:10.1111/ijd.12690.

49. Cabillos MR, Leelin-Sarrosa DM, Verallo-Rowell VM. Green tea extract cream (epigallocatechin gallate) in the treatment of molluscum contagiosum: A randomized, double-blind, vehicle-controlled trial. J Phil Dermatol Soc. 2003; 12(2):21-7. 
50. Moreno-Alsalsua M. Randomized controlled trial on the effect of coconut oil, vinegar plus cooking coconut oil versus $1 \%$ permethrin shampoo in the treatment of pediculosis. Ped Infect Dis Soc Phil J. 2016;17(2):4-13.

51. Castillo A, Osi MO, Ramos JD, De Francia JL, Dujunco MU, Quilala PF. Efficacy and safety of Tinospora cordifolia lotion in Sarcoptes scabiei var hominis-infected pediatric patients: A single blind, randomized controlled trial. J Pharmacol Pharmacother. 2013; 4(1):39-46. doi:10.4103/0976-500X.107668.

52. Naagas V, Medel R, Angeles C, Ampil II. A randomized controlled trial comparing the efficacy of $10 \%$ guava extract shampoo versus $2 \%$ ketoconazole shampoo and clobetasol $0.05 \%$ shampoo in the treatment of scalp seborrheic dermatitis. J Phil Dermatol Soc. 2013; 22(1):17-22. doi:10.1227/01.NEU.0000317272.86593.E3.

53. Concepcion MC, de Jesus LC, Santos-Acuin C. A study on the efficacy and safety of $50 \%$ akapulco lotion in the treatment of scabies. Fil Fam Phy. 1999; 37(1):3-9.

54. Ong-Salvador SL, King-Ismael D. Comparative in-vitro and in-vivo study of the efficacy of topical aromatic oils versus $1 \%$ lindane shampoo in the treatment of pediculosis capitis. J Phil Dermatol Soc. 2000; 9(2):91-5.

55. Cue PCC, Paliza AC, Torres RC. A double-blind, randomized controlled trial on the effectiveness of $10 \%$ lemongrass oil (Cymbopogon citratus) vs. 1\% clotrimazole solution in treating tinea corporis and tinea cruris. J Phil Dermatol Soc. 2010; 19(1):2-7.

56. Perez-Chua TAP, Paliza AC, Castillo AL. Randomized, assessor-blind, controlled clinical trial on the efficacy and safety of aromatic oil (10\% eucalyptus oil, $10 \%$ lavender oil, 10\% rosemary oil) shampoo versus $1 \%$ permethrin shampoo in the treatment of pediculosis capitis. J Phil Dermatol Soc. 2012; 23-9.

57. de las Alas JMG, Carpio VM, Lim MEL, Frez MLF. Randomized controlled trial on the efficacy and safety of virgin coconut oil compared to mineral oil in the treatment of uremic xerosis. Acta Med Philipp. 2014; 48(4):35-42.

58. Ramiro R, Resureccion M. A randomized controlled community trial on the efficacy of virgin coconut oil, 70\% isopropyl alcohol and virgin coconut oil as compared to permethrin in the treatment of Pediculosis human capitis in children 2 to 19 years old. Phil J Ped. 2014; 62(1):35-42.

59. Leon-Godinez M de, Teodosio G, Gabriel M, Mendoza C, Co CC. A randomized, double-blind, placebo-controlled study on the safety and efficacy of $0.025 \%$ capsaicin (Capsicum annuum var. longum) cream against $1 \%$ hydrocortisone cream as an anti-inflammatory and anti-pruritic preparation for mosquito bites. J Phil Dermatol Soc. 2009; 20(2):26-35. doi:10.1177/1740774509104992.

60. Rivera EF, Sison EM, Aligui GL. A Comparative study of the efficacy of crotamiton and Tinosphora rumphii in the treatment of scabies in children. J Phil Med Assoc. 1983; 58(7):265-7.

61. de Leon-Pandanan AT, Dizon JA, Regalado-Morales E, dL Carpio B. Akapulco cream An effective alternative therapy for pityriasis versicolor in patients of the Ospital ng Maynila Medical Center Section of Dermatology. J Phil Soc Cutan Med. 2002; 3(1):51-5.
62. Sayo-Bondoc C, dL Carpio B, Regalado-Morales E, LapitanTorres A, Yason JR. A double-blind, randomized controlled trial on the effectiveness and safety of $15 \%$ malunggay ointment (Moringa oleifera) vs $2 \%$ mupirocin ointment in treating localized pyoderma. J Phil Dermatol Soc. 2016; 25(1):11-8.

63. Despuig EF, Domingo PI, Feliciano KS, Casama FA, Carballo MIA, Chan CE, et al. A comparative study of the effectiveness of tea tree oil and benzoyl peroxide in the treatment of acne vulgaris among Filipino teenagers and adults in Metro Manila. UERMMMC Heal Sci J. 2016; 5(1):3-7.

64. Tavanlor-Amado AGC, Cubillan ELA, Angeles CB, Talens ES. An evaluator-blinded, randomized controlled trial comparing the efficacy, tolerability and safety of Carica papaya latex extract cream versus trichloroacetic acid $85 \%$ solution in the treatment of verruca. J Phil Dermatol Soc. 2014; 23(2):18-26.

65. Lazo-Dizon JPH, Salud CMD, Jr MOF, Cubillan ELA, Datuin MSL. Topical cashew nut extract (DeBCC) for the treatment of basal cell carcinoma: A randomized double-blind, vehicle-controlled trial. Acta Med Philipp. 2013; 47(4):45-51.

66. Uy JCN. Randomized controlled trial on the use of guava leaves (Psidium guajava linn.) decoction as an adjunct to conventional treatment (cloxacillin) of ecthyma among schoolchildren. Phil J Ped. 2003; 52(3):162-6.

67. Dofitas B, Chan B, Reyes R, Guloy N, Maramba N. A randomized controlled trial on the efficacy and safety of $50 \%$ akapulko lotion compared with $25 \%$ sodium thiosulfate lotion among patients with tinea versicolor. J Phil Dermatol Soc. 2001; 10(1):10-6.

68. Elbo AMF, Echiverri CMS, Dy Tiapco RPT, Dumlao LCI, Dumlao AC, Paredes GT, et al. A 2-week comparative study on the efficacy of 2 different concentrations of acapulco ointment among residents in two barangays in Metro Manila with tinea pedis using a randomized experimental design . UERMMMC J Heal Sci. 2002; 5(1):35-45.

69. Llamasares-de Franci J, Yoro MS. A comparative study of the efficacy of formulated Tinospora rumphii Boerl. lotion and Crotamiton in the treatment of scabies in children. Phil J Ped. 2005; 54(4):198-203.

70. Evangelista MT, Abad-Casintahan F, Lopez-Villafuerte L. The effect of topical virgin coconut oil on SCORAD index, transepidermal water loss and skin capacitance in mild to moderate pediatric atopic dermatitis: A randomized, double-blind clinical trial. Int J Dermatol. 2014; 53(1):100-8. doi:10.1111/ijd.12339.

71. Division D of HP. Philippine National Drug Formulary 8th Ed [Internet]. [cited 2018 Jul]. Available from https://www.philhealth. gov.ph/partners/providers/pdf/PNF_09072018.pdf.

72. Lazarte MCM, Cortes-Maramba NP, Palacpac JB, et al., eds. Chapter 4. Medicinal plants for common symptoms and diseases. In: Guidelines in the Proper Use of Medicinal Plant, 6th ed. 2017; 122-169.

73. Philippine Dermatological Society. Regional Congress of Dermatology E-Poster Proceedings. 2012. 


\section{APPENDICES}

Appendix 1. List of commonly used herbs for skin diseases ${ }^{72}$

\begin{tabular}{|c|c|c|}
\hline Skin disease & Common name & Scientific name \\
\hline Abscess & $\begin{array}{l}\text { Bayabas or guava } \\
\text { Gumamela } \\
\text { Kamantigi or kamantigue } \\
\text { Kalachuchi } \\
\text { Pili }\end{array}$ & $\begin{array}{l}\text { Psidium guajava } \mathrm{L} . \\
\text { Hibiscus rosa-sinensis } \mathrm{L} . \\
\text { Impatiens balsamina } \mathrm{L} \text {. } \\
\text { Plumeria rubra L./Plumeria acuminata W.T Aiton } \\
\text { Canarium ovatum Engl. }\end{array}$ \\
\hline Burns & $\begin{array}{l}\text { Gumamela } \\
\text { Oregano }\end{array}$ & $\begin{array}{l}\text { Hibiscus rosa-sinensis L. } \\
\text { Plectranthus amboinicus (Lour.) Spreng. }\end{array}$ \\
\hline Falling hair & Coconut & Cocos nucifera L. \\
\hline Itching & $\begin{array}{l}\text { Bayabas } \\
\text { Kakawati or kakawate or madre de cacao } \\
\text { Kamoteng kahoy }\end{array}$ & $\begin{array}{l}\text { Psidium guajava L. } \\
\text { Gliciridia sepium (Jacq.) Walp. } \\
\text { Manihot esculenta Crantz }\end{array}$ \\
\hline Scabies & $\begin{array}{l}\text { Kakawati or kakawate or madre de cacao } \\
\text { Makabuhay } \\
\text { Akapulko or akapulco or acapulco or acapulko }\end{array}$ & $\begin{array}{l}\text { Gliciridia sepium (Jacq.) Walp. } \\
\text { Tinospora rumphii Boerl./Tinospora cordifolia (Willd.) Miers } \\
\text { Senna alata (L.) Roxb./Cassia alata L }\end{array}$ \\
\hline $\begin{array}{l}\text { Tinea, ringworm and } \\
\text { athlete's foot }\end{array}$ & $\begin{array}{l}\text { Tanglad } \\
\text { Bawang } \\
\text { Akapulko or akapulco or acapulco or acapulko }\end{array}$ & $\begin{array}{l}\text { Cymbopogon citratus (DC.) Stapf } \\
\text { Allium sativum L. } \\
\text { Senna alata (L.) Roxb./Cassia alata L. }\end{array}$ \\
\hline $\begin{array}{l}\text { Infected wounds/ } \\
\text { skin ulcers }\end{array}$ & $\begin{array}{l}\text { Bayabas or guava } \\
\text { Gumamela } \\
\text { Kamantigi or kamantigue } \\
\text { Kalachuchi }\end{array}$ & $\begin{array}{l}\text { Psidium guajava } \mathrm{L} \text {. } \\
\text { Hibiscus rosa-sinensis } \mathrm{L} \text {. } \\
\text { Impatiens balsamina } \mathrm{L} \text {. } \\
\text { Plumeria rubra L./Plumeria acuminata W.T Aiton }\end{array}$ \\
\hline Others ${ }^{73}$ & $\begin{array}{l}\text { Aloe } \\
\text { Calamansi or Kalamansi } \\
\text { Cashew } \\
\text { Siling labuyo or siling haba or Chili or cayenne pepper } \\
\text { Green tea } \\
\text { Malunggay } \\
\text { Neem } \\
\text { Papaya }\end{array}$ & $\begin{array}{l}\text { Aloe vera (L.) Burm.f. } \\
\text { Citrus x microcarpa Bunge } \\
\text { Anacardium occidentale L. } \\
\text { Capsicum frutescens L.,/Capsicum annuum L. } \\
\text { Camellia sinensis (L.) Kuntze } \\
\text { Moringa oleifera Lam. } \\
\text { Azadirachta indica A. Juss. } \\
\text { Carica papaya L. }\end{array}$ \\
\hline
\end{tabular}

Appendix 2. Search strategy for medline (PubMed)

\begin{tabular}{|c|c|c|}
\hline Search & Query & Items found \\
\hline$\# 5$ & $\begin{array}{l}\text { Search ((((dermatol*) OR cutaneous) OR skin)) AND (("randomized controlled trial"[Publication Type]) AND } \\
(((\text { Philippine*) OR Filipin*)) }\end{array}$ & 23 \\
\hline \#4 & Search ("randomized controlled trial"[Publication Type]) AND ((Philippine*) OR Filipin*) & 352 \\
\hline \#3 & Search ((dermatol*) OR cutaneous) OR skin & 1008660 \\
\hline \#2 & Search (Philippine*) OR Filipin* & 17819 \\
\hline \#1 & Search "randomized controlled trial"[Publication Type] & 468918 \\
\hline
\end{tabular}


Appendix 3. Characteristics of included studies

\begin{tabular}{|c|c|c|c|}
\hline Study ID & Herb/Part/Preparation & Disease & Institution Of Main Author \\
\hline 1. Abdujarak $2017^{31}$ & Malunggay leaf extract gel & Acne vulgaris & $\begin{array}{l}\text { Ateneo de Zamboanga University - } \\
\text { College of Medicine }\end{array}$ \\
\hline 2. Agero $2004^{33}$ & Extra virgin coconut oil & Xerosis & $\begin{array}{l}\text { Makati Medical Center - Dept. of } \\
\text { Dermatology }\end{array}$ \\
\hline 3. Aguilar $2004^{35}$ & $\begin{array}{l}\text { Akapulko leaf extract } 75 \% \text { aqeous } \\
\text { solution }\end{array}$ & $\begin{array}{l}\text { Dermato-phytoses (tinea } \\
\text { pedis) }\end{array}$ & UERM - College of Medicine \\
\hline 4. Alayon $2002^{37}$ & Akapulko leaf $80 \%$ lotion & Scabies & $\begin{array}{l}\text { De La Salle University Health Sciences } \\
\text { Institute - Dept. of Family Medicine }\end{array}$ \\
\hline 5. Alvin $2011^{39}$ & Mulberry (Morus alba) 75\% Extract Oil & Melasma & Skin Cancer Foundation, Inc. \\
\hline 6. Ancheta $2004^{41}$ & Kakawati soap and ointment & Scabies & UERM - College of Medicine \\
\hline 7. Bañez $1999^{43}$ & Kakawati lotion & Scabies & UERMMMC - Dept. of Dermatology \\
\hline 8. Banzon $2008^{45}$ & Siling labuyo $50 \%$ and $75 \%$ ointment & Pain & RITM - Dept. of Dermatology \\
\hline 9. Buensalido $2011^{47}$ & Papaya fruit latex $1.5 \%$ cream & $\begin{array}{l}\text { Dermato-phytoses (tinea } \\
\text { corporis) }\end{array}$ & $\begin{array}{l}\text { Makati Medical Center - Dept. of } \\
\text { Dermatology }\end{array}$ \\
\hline 10. Cabillos $2003^{49}$ & Green tea extract $5 \%$ cream & Molluscum contagiosum & $\begin{array}{l}\text { Makati Medical Center - Dept. of } \\
\text { Dermatology }\end{array}$ \\
\hline 11. Castillo $2013^{51}$ & Makabuhay extract lotion & Scabies & UST - Pharmacy Department \\
\hline 12. Concepcion $1999^{53}$ & Akapulko $50 \%$ lotion & Scabies & $\begin{array}{l}\text { De La Salle University Health Sciences } \\
\text { Institute - Dept. of Family Medicine }\end{array}$ \\
\hline 13. Cue $2010^{55}$ & Lemongrass $10 \%$ oil & $\begin{array}{l}\text { Dermato-phytoses (tinea } \\
\text { corporis and cruris) }\end{array}$ & STUH - Dept. of Dermatology \\
\hline 14. De Las Alas $2014^{57}$ & Virgin coconut oil & Uremic xerosis & PGH - Section of Dermatology \\
\hline 15. De Leon-Godinez $2011^{59}$ & Siling haba $0.025 \%$ cream & Mosquito bites & RITM - Dept. of Dermatology \\
\hline 16. De Leon-Pandanan $2002^{61}$ & Akapulko cream & Tinea versicolor & OMMC - Dept. of Dermatology \\
\hline 17. Despuig $2016^{63}$ & Tea tree oil & Acne vulgaris & $\begin{array}{l}\text { UERMMMC - Dept. of Preventive and } \\
\text { Community Medicine }\end{array}$ \\
\hline 18. Dizon $2013^{65}$ & $\begin{array}{l}\text { Cashew nut pericarp extract cream } \\
\text { (DeBCC) }\end{array}$ & Basal cell carcinoma & PGH - Section of Dermatology \\
\hline 19. Dofitas $2001^{67}$ & Akapulko $50 \%$ lotion & Tinea versicolor & PGH - Section of Dermatology \\
\hline 20. Dumlao $2002^{68}$ & Akapulko 7.5 \& $15 \%$ ointment & $\begin{array}{l}\text { Dermato-phytoses } \\
\text { (tinea pedis) }\end{array}$ & UERMMMC - Dept. of Dermatology \\
\hline 21. Evangelista $2014^{70}$ & Virgin coconut oil & Atopic dermatitis & JRRMMC - Dept. of Dermatology \\
\hline 22. Francisco-Diaz $2004^{32}$ & $\begin{array}{l}\text { Gigawhite } 5 \% \text { solution (Various - mallow, } \\
\text { peppermint, primrose, lady's mantle, } \\
\text { lemon balm, yarrow) }\end{array}$ & Melasma & Skin Cancer Foundation, Inc. \\
\hline 23. Gan $2003^{34}$ & Green tea $3 \%$ extract cream & Acne vulgaris & JRRMMC - Dept. of Dermatology \\
\hline 24. Guillano $2005^{36}$ & Kakawati $50 \%$ ointment & $\begin{array}{l}\text { Dermato-phytosis } \\
\text { (tinea corporis and cruris) }\end{array}$ & $\begin{array}{l}\text { Davao Medical Center (DMC) - Dept. } \\
\text { of Dermatology }\end{array}$ \\
\hline 25. Hau $2008^{38}$ & Ginger rhizome powder 25 mg/g Cream & $\begin{array}{l}\text { Dermato-phytosis } \\
\text { (tinea corporis and cruris) }\end{array}$ & JRRMMC - Dept. of Dermatology \\
\hline 26. Lagunzad $2013^{40}$ & Apple cider vinegar & Common warts & UERMMMC - Dept. of Dermatology \\
\hline
\end{tabular}




\begin{tabular}{|c|c|c|c|c|c|}
\hline $\begin{array}{l}\text { Journal } \\
\text { Published }\end{array}$ & $\begin{array}{l}\text { Sample } \\
\text { Size }\end{array}$ & Study Setting And Study Population & $\begin{array}{l}\text { Duration Of } \\
\text { Follow-Up }\end{array}$ & $\begin{array}{l}\text { Ethical } \\
\text { Approval }\end{array}$ & Study Funding \\
\hline PJP & 34 & $\begin{array}{l}\text { School: Boniao National High School, Mahayag, } \\
\text { Zamboanga del Sur } \\
\text { Male high school students; age not stated }\end{array}$ & 6 wks. & Y & NS \\
\hline Dermatitis & 34 & $\begin{array}{l}\text { Dermatology clinic } \\
16-70 \text { year old }\end{array}$ & 2 wks. & Y & NS \\
\hline UERM JHS & 22 & $\begin{array}{l}\text { Community: Brgy. Damayan Lagi and Brgy. 48-B } \\
\text { Kapiligan } \\
\text { Age not stated }\end{array}$ & 4 wks. & NS & NS \\
\hline FFP & 120 & $\begin{array}{l}\text { General clinic, Dasmariñas, Cavite } \\
\text { Age not stated }\end{array}$ & 3 days & NS & NS \\
\hline JDD & 50 & $\begin{array}{l}\text { Dermatology clinic of a charity hospital in Makati } \\
\text { Adults }\end{array}$ & 8 wks. & Y & NS \\
\hline UERM JHS & 49 & $\begin{array}{l}\text { Orphanage } \\
\text { 3-18 years old }\end{array}$ & 7 days & NS & NS \\
\hline PJMID & 44 & $\begin{array}{l}\text { Bagong Nayon II } \\
\text { All ages }\end{array}$ & 5 days & NS & NS \\
\hline JPDS & 85 & $\begin{array}{l}\text { Dermatology OPD, RITM } \\
\text { Adults aged } 18-60 \text { years old }\end{array}$ & 9 days & NS & NS \\
\hline JPDS & 60 & $\begin{array}{l}\text { NS } \\
\text { Age not stated }\end{array}$ & 6 mos. & Y & $\mathrm{N}$ \\
\hline JPDS & 69 & $\begin{array}{l}\text { Makati Medical Center OPD } \\
\text { Children and young adults }\end{array}$ & NS & Y & NS \\
\hline $\begin{array}{l}\text { J Pharmacol } \\
\text { Pharmacother }\end{array}$ & 66 & $\begin{array}{l}\text { Manila Youth Reception Center, Reception Action } \\
\text { Center and Tanglao Detention Center, Malolos, Bulacan } \\
2-22 \text { years old }\end{array}$ & 4 wks. & Y & $\begin{array}{l}\text { Y, Science Education Institute, } \\
\text { DOST, CHED, FAPE, and the UST } \\
\text { Grants Office, (Philippines) }\end{array}$ \\
\hline FFP & 100 & $\begin{array}{l}\text { Not stated } \\
7-30 \text { years old }\end{array}$ & 4 wks. & NS & NS \\
\hline JPDS & 96 & $\begin{array}{l}\text { Not stated } \\
2-70 \text { years old }\end{array}$ & 4 wks. & Y & $\mathrm{N}$ \\
\hline $\begin{array}{l}\text { Acta Medica } \\
\text { Philippina } \\
\end{array}$ & 45 & $\begin{array}{l}\text { Dialysis Unit, PGH } \\
\text { Adult patients }\end{array}$ & 4 wks. & Y & Y, PDS \\
\hline JPDS & 75 & $\begin{array}{l}\text { Dermatology and Entomology Laboratory, RITM } \\
18 \text { to } 60 \text { years old }\end{array}$ & $1 \mathrm{mo}$. & NS & $\mathrm{N}$ \\
\hline JPSCM & 150 & $\begin{array}{l}\text { Dermatology Clinic, OMMC } \\
\text { Adults }\end{array}$ & 4 wks. & NS & $\mathrm{N}$ \\
\hline UERM JHS & 70 & $\begin{array}{l}\text { Community in Brgy. Doña Imelda } \\
\text { Children and adults }\end{array}$ & 4 wks. & Y & NS \\
\hline $\begin{array}{l}\text { Acta Medica } \\
\text { Philippina }\end{array}$ & 19 & $\begin{array}{l}\text { PGH Outpatient Department, Section of Dermatology } \\
\text { Adult patients }\end{array}$ & 8 wks. & Y & $\begin{array}{l}\text { Y, } \\
\text { NIH and PCHRD. Study drugs } \\
\text { by RCC Amazing Touch. }\end{array}$ \\
\hline JPDS & 129 & $\begin{array}{l}\text { Dermatology clinic of PGH } \\
\text { 7-65 years old }\end{array}$ & NS & NS & Y, PCHRD \\
\hline UERM JHS & 43 & $\begin{array}{l}\text { Brgy. Bagong Silang, Cainta, Rizal and Brgy. Doña } \\
\text { Imelda, QC } \\
\text { Any age }\end{array}$ & 2 wks. & NS & NS \\
\hline IJD & 117 & $\begin{array}{l}\text { Dermatology OPD in JRRMMC } \\
\text { Children } 1-13 \text { years old }\end{array}$ & 8 wks. & NS & NS \\
\hline JPDS & 28 & $\begin{array}{l}\text { Makati Medical Center } \\
\text { Adults }\end{array}$ & NS & NS & NS \\
\hline JPSCM & 108 & $\begin{array}{l}\text { Tertiary hospital } \\
\text { Age not stated }\end{array}$ & 12 wks. & NS & NS \\
\hline JPDS & 40 & $\begin{array}{l}\text { DMC dermatology clinic } \\
7-79 \text { years old }\end{array}$ & 4 wks. & NS & NS \\
\hline JPDS & 24 & $\begin{array}{l}\text { Not stated } \\
12-70 \text { years old }\end{array}$ & 8 wks. & NS & NS \\
\hline JPDS & 27 & $\begin{array}{l}\text { STUH- OPD } \\
2-60 \text { years old }\end{array}$ & 5 wks. & $Y$ & $\mathrm{~N}$ \\
\hline
\end{tabular}




\section{Assessing hCONSORT}

\begin{tabular}{llll}
\hline 27. Lisdyanti 201142 & Aloe vera with vitamin E cream & Surgical wounds & $\begin{array}{l}\text { De Los Santos-STI Medical Center - } \\
\text { Dept. of OB-Gynecology }\end{array}$ \\
\hline 28. Lombos 201544 & Tea tree oil & Common warts & $\begin{array}{l}\text { East Avenue Medical Center - Dept. of } \\
\text { Dermatology }\end{array}$ \\
\hline 29. Martinez 201446 & Citronella shampoo (Lyecare) & Head lice & $\begin{array}{l}\text { MPI-Medical Center Muntinlupa - } \\
\text { Dept. of Pediatrics }\end{array}$
\end{tabular}

\begin{tabular}{llll}
\hline 30. Mendoza 201448 & Western dock 3\% cream & Melasma & RITM - Dept. of Dermatology \\
\hline 31. Moreno 2016 & Cooking coconut oil & Head lice & OMMC - Dept. of Dermatology \\
\hline 32. Naagas-Sarmiento 201352 & Guava extract 10\% shampoo & Seborrheic dermatitis & UERMMMC - Dept. of Dermatology \\
\hline 33. Ong-Salvador 200054 & $\begin{array}{l}\text { Lavender, rosemary, eucalyptus in } \\
\text { sunflower oil }\end{array}$ & Head lice & STUH - Dept. of Dermatology \\
\hline 34. Perez-Chua 201256 & $\begin{array}{l}\text { Lavender, rosemary, eucalyptus in } \\
\text { sunflower oil }\end{array}$ & Head lice & STUH - Dept. of Dermatology \\
\hline 35. Ramiro 201458 & Virgin coconut oil & Head lice & $\begin{array}{l}\text { Veterans Memorial Medical Center - } \\
\text { Dept. of Pediatrics }\end{array}$
\end{tabular}

\begin{tabular}{llll}
\hline 36. Rivera 198360 & Makabuhay 4\% aqeous solution & Scabies & Not stated \\
\hline 37. Sayo-Bondoc 201662 & Malunggay 15\% ointment & Localized pyoderma & OMMC - Dept. of Dermatology \\
\hline 38. Tavanlar-Amado 201464 & $\begin{array}{l}\text { Papaya latex extract cream } \\
\text { (BlemishOFf Herbocautery cream) }\end{array}$ & Warts & UERMMMC - Dept. of Dermatology \\
\hline 39. Uy 200366 & Guava leaf 0.25\% decoction & Ecthyma & $\begin{array}{l}\text { Iloilo Mission Hospital - Dept. of } \\
\text { Pediatrics }\end{array}$ \\
\hline 40. Verallo-Rowell 2008 & Virgin coconut oil & Atopic dermatitis & Skin Cancer Foundation, Inc. \\
\hline 41. Yoro 200569 & Makabuhay lotion & Scabies & $\begin{array}{l}\text { St. Luke's Medical Center - Dept. of } \\
\text { Pediatrics }\end{array}$ \\
\hline
\end{tabular}

Legend: UERMMMC University of the East-Ramon Magsaysay Memorial Medical Center; PJP Philippine Journal of Pediatrics; UERM JHS Journal of Health Sciences; FFP The Filipino Family Physician; JDD Journal of Drugs in Dermatology; PJMID Philippine Journal of Microbiology and Infectious Diseases; RITM Research Institute of Tropical Medicine; JPDS Journal of the Philippine Dermatological Society; JRRMMC Jose R. Reyes Memorial Medical Center; JPSCM Journal of the Phil. Society of Cutaneous Medicine; PGH Philippine General Hospital; IJD International Journal of Dermatology; STUH Santo Tomas University Hospital; OMMC Ospital ng Maynila Medical Center; JPMA Journal of the Philippine Medical Association 


\begin{tabular}{|c|c|c|c|c|c|}
\hline PJOG & 101 & $\begin{array}{l}\text { Department of Obstetrics and Gynecology } \\
\text { Adults }\end{array}$ & 11 mos. & $\mathrm{Y}$ & NS \\
\hline JPMA & 20 & $\begin{array}{l}\text { Dermatology clinic, EAMC } \\
8-45 \text { years old }\end{array}$ & 4 wks. & $\mathrm{Y}$ & NS \\
\hline PIDSPJ & 86 & $\begin{array}{l}\text { MPI PNR (Philippine National Railway) Site, Putatan, } \\
\text { Muntinlupa City } \\
\text { Children up to } 15 \text { years old }\end{array}$ & NS & $Y$ & NS \\
\hline IJD & 45 & $\begin{array}{l}\text { Dermatology clinic, RITM } \\
\text { Adults } 18-60 \text { years old }\end{array}$ & 8 wks. & NS & NS \\
\hline PIDSPJ & 150 & $\begin{array}{l}\text { Barangay } 704 \text {, Zone } 77 \text { malate Manila } \\
1-12 \text { years old }\end{array}$ & 14 days & $\mathrm{Y}$ & NS \\
\hline JPDS & 45 & $\begin{array}{l}\text { Dermatology clinic, UERMMMC } \\
18-60 \text { years old }\end{array}$ & 4 mos. & $\mathrm{Y}$ & $\mathrm{N}$ \\
\hline JPDS & 272 & $\begin{array}{l}\text { Selected orphanages in Metro Manila } \\
6-15 \text { years old }\end{array}$ & $1 \mathrm{yr}$. & NS & Y, PCHRD \\
\hline JPDS & 154 & $\begin{array}{l}\text { Community in Bulacan } \\
\text { Children, Adults, and Elderly }\end{array}$ & 3 wks. & $\mathrm{Y}$ & $\mathrm{N}$ \\
\hline PJP & 180 & $\begin{array}{l}\text { Gawad Kalinga, Bagong Silangan and Our Lady of the } \\
\text { Star Daycare Center, Caloocan City } \\
2-19 \text { years old }\end{array}$ & 14 days & $\mathrm{Y}$ & NS \\
\hline JPMA & 91 & $\begin{array}{l}\text { Reception and Study Center for Children in Quezon } \\
\text { City } \\
2 \text { mos. to } 8 \text { years old }\end{array}$ & NS & NS & NS \\
\hline JPDS & 66 & $\begin{array}{l}\text { Department of dermatology, OMMC } \\
6-15 \text { years old }\end{array}$ & 4 mos. & $Y$ & $\mathrm{~N}$ \\
\hline JPDS & 74 & $\begin{array}{l}\text { Dermatology OPD, UERMMMC } \\
5-70 \text { years old }\end{array}$ & 6 mos. & $\mathrm{Y}$ & NS \\
\hline PJP & 58 & $\begin{array}{l}3 \text { rural public elementary schools in Miag-ao, lloilo, } \\
\text { Philippines } \\
\text { Children; no age stated }\end{array}$ & 41 days & NS & NS \\
\hline Dermatitis & 52 & $\begin{array}{l}2 \text { general dermatology Clinics } \\
18 \text { to } 40 \text { years old }\end{array}$ & 4 wks. & NS & Y, Skin Sciences Laboratory, Inc. \\
\hline PJP & 55 & $\begin{array}{l}\text { Manila Boys town Complex, Girls' Home } \\
2-17 \text { year old females }\end{array}$ & NS & NS & NS \\
\hline
\end{tabular}

